\title{
A Place for Agency, a Place for Positivism, a Place for Both over the Life Course
}

\author{
Alex R. Piquero ${ }^{1,2}$ \\ Published online: 12 September 2019 \\ (C) Springer Nature Switzerland AG 2019
}

"Why don't you meet me in the middle, middle." Maren Morris "Middle"

When I woke up this morning, I got out of bed, opened my bedroom door, went to the other side of the house, into the home office, turned on the computer, logged in, and opened up my word processing program. I then proceeded to create a new document and stared at the white screen familiar to us all. I did all of these acts purposefully and of my own accord. As a tenured, full professor nothing made me undertake all those steps on this particular morning.

Yet, I also knew that while I did not necessarily need to work on this comment, I wanted to do so. I was excited about the idea in my head regarding what I thought the perfect opening paragraph would be. That excitement notwithstanding, I also knew that I had a deadline to get the paper submitted to the editor in a month's time so I needed to work on it little by little rather than making a push at the end. So, in one sense, I had human agency, I did all of those things in the first paragraph purposefully, but in another sense I have a deadline to make and a career that requires me to write (and teach and perform service). So, in another sense, while I had and executed my agency, I had some external pressures to do so and thus my agency was affected by them.

Fast forward to twenty years from now, when I will certainly be in late academichood, will I have the same human agency that I had when I started my career? Sure, I may still have some pressure to write, but it may be more external than internal (unless of course my identity is such that writing becomes part of who I am-almost habit-like, not something that I need to do for my job-more on this later). The rewards and

Alex R. Piquero

apiquero@utdallas.edu

1 University of Texas at Dallas, Richardson, TX, USA

2 Monash University, Melbourne, Australia 
accolades of publishing one more paper at age 68 may matter less than they did when I became a tenure-track Assistant Professor.

In December 2017, JDLCC published a paper by Paternoster that focused on the importance of human agency for criminology, arguing forcefully that human agency should be a background assumption. In this article, he called attention to the lack of (theoretical and definitional) specification in many desistance theories of crime that claim to have a key role for human agency in the cessation of crime but do not develop the concept further and instead prioritize "event causality" or that things happen to persons that lead them to change (desist). ${ }^{1}$ For Paternoster, human agency amounts to action, "deliberate and intended or willed conduct" (p.350). ${ }^{2}$ Everything I talked about in the first paragraph was deliberate, intended, and focused on an outcome. I could have easily slept in, gone for a run, watched television-you know procrastinatesomething which all academics tend to do every once in a while! But I purposely did something because I wanted to achieve something even when other options were available.

In a reaction piece, Cullen [2] recognized the value of human agency, but was concerned with Paternoster's call that it be embraced as criminology's background assumption. In this regard, Cullen argues that making human agency so central in criminology would not permit scientific analysis. In outlining his critique, Cullen noted five reservations about human agency and its usefulness for criminology. First, he argues that positivism is unavoidable and takes offense that Paternoster does not see his view of human agency as an empirical question because Cullen believes that the field's primary interest is to search for factors that cause certain choices to be made (p. 375, emphasis in original). Second, Cullen takes issue with Paternoster's (initial, at least in this paper) focus of human agency for adulthood to the detriment of studying the "intersecting causes [of crime] across the life course" (p.375). Next, Cullen observes that agency may be more or less salient at some times than others, but it is important to understand why it failed in previous attempts (his example of weight loss) but became successful at a recent attempt. Fourth, Cullen appears to see little value in - and more risk for-advocating for one particular background assumption. For Cullen, assumptions, and correlates and causes, are all empirical questions. Lastly, he argues that human agency may legitimize punitive justice policies. This is so because Paternoster's view of human agency has persons knowingly do something through their own volition. Therefore, one could argue that sex offenders want to be sex offenders, drug addicts want to be drug addicts, and prostitutes want to be prostitutes. I think that human agency may fall prey to this argument for some crime types (that may be influenced by personal and/or socioeconomic factors that may influence and/or constrain one's human agency) than say

\footnotetext{
${ }^{1}$ In particular, Paternoster [7] is primarily concerned with Laub and Sampson's view of desistance: "[S]ecuring jobs and entering into satisfying social relationships are the antecedent events which bring about a change in offenders' routine activities. This change in routine activities, in turn, results in greater monitoring and supervision (more intense informal social control), and it is this that ultimately leads one away from crime."

${ }^{2}$ Lest the reader rely too much on my interpretation of Paternoster's [7] concept of human agency, it bears repeating here: "...[H]uman agency consists of deliberation and the making of decisions, the formation of an intention or purpose for the action, the execution of that intention by volition (willed actions), and guiding our actions to stay aligned with our purpose until that purpose is satisfied or we change it."
} 
other crimes, like terrorism (flying a plane into the Twin Towers) which have planning and purpose for a specific outcome. In my mind, then, human agency, while lying on some sort of continuum, may be more relevant (and of use) for some crime types than others. But this, of course, is, and I agree with Cullen on this, an empirical question.

Fast forward to Brezina's insightful argument [1] which offers a theoretical middle-ground in the form of an alternative conceptualization of human agency, rooted in Bandura's sociocognitive approach to agency, that avoids the potential pitfalls noted by Cullen but remains friendly to the essence of Paternoster's argument by focusing on the conditions under which the exercise of agency is more or less likely to occur. Brezina's conceptualization of agency is compatible with the positivist nature found in much criminological theory. He achieves this by (1) arguing that agency depends on capacities and resources - which vary between and within persons over the life course and (2) offering a key mechanism of agency, selfefficacy, or the level of confidence/capability one has in their ability to organize and act in a way that is aimed at producing a specific and desired outcome, which is measurable and therefore friendly to Cullen's point that agency should be a measure more than an organizing assumption. Brezina's piece is not just thought-provoking. It is a path forward ripe with an array of potential research questions that he dutifully provides the reader.

I think there is little doubt that there is some element of decision-making (choice) in all human behavior. If we have learned anything from the famous song "Free Will" by the Canadian rock trio Rush it is that "If you choose not to decide you still have made a choice." The issues that affect the decision to choose a course of action are potentially influenced by one or maybe several factors. Choices made when sober may look very different from choices made when one is under the influence of drugs or alcohol. Choices made at age 14 may not be the same kinds of choices made at age 45 when one may not be hanging out with delinquent peers or seeking adult status. Choices made under fits of anger are likely to be different than choices made when one is calm. Choices may also be reflective of experiences and the outcomes of those experiences. For example, one learns to drive in the mid-teens but the experience of driving every day and under multiple conditions (rain, snow, highways, on-ramps, traffic) helps an individual think about the kinds of things to think about going on the next errand (i.e., is that person going to cut me off or why is their blinker still on). And to make an academic analogy, we all remember our first organized class and our first manuscript submission. Hopefully, experiences make us better as we get more seasoned in academia because we learn how to teach, what students like or do not like, and we start to think about the potential comments that a reviewer will raise regarding a particular measure or method of analysis.

What makes Brezina's middle-ground position so appealing is that it is rooted in what we know about decision-making over the life course. Yes, we have human agency. But that agency is also influenced and/or constrained by what we come to the table with and what factors influence us at different periods of the life course. ${ }^{3}$ Two examples, one criminological and one criminal justice related are pertinent here. A key

\footnotetext{
${ }^{3}$ This conditional approach is one that has been referenced to in other theoretical models (notably Wikström's Situational Action Theory; [12]) as well as the research on deterrence more generally [11].
} 
feature of criminal careers is the recognition that there is an intermittent or zig-zag pattern to offending over the life course $[8,10]$. That is, offenders do not always offend and oftentimes take breaks within their criminal career, whether days, weeks, months, or even years. Moreover, these breaks could be due to a variety of factors, including human agency as well factors surrounding the offender. Laub and Sampson's [5] interviews with several of the Glueck males in late adulthood reveal an interesting interplay between purposeful choices as well as factors that may influence those choices, especially wives. Thus, while the men did ultimately decide to act in a crime-free way, those decisions were, in part, related to other sources of informal social control around them. As the theorists note (p. 282), "The view of individual choice extends well beyond selection effects - structures are determined by individual choices, and in turn structures constrain, modify, and limit individual choices...we believe that the interaction of choice and structure produces behavior that cannot be predicted from a focus on one or the other."

A second, criminal-justice-oriented example of the appropriateness of Brezina's middle-ground position, and one that contradicts one of Cullen's fears of Paternoster's agency-centered framework regarding the potential for punitive crime control policies, may be found in the research on adolescence and adolescent decision-making used in four Supreme Court cases in the first part of the twenty-first century, Roper v. Simmons, Graham V. Florida, Miller v. Alabama, and Jackson v. Hobbs. The decisions reached in these cases "helped spur a reconsideration of the assumptions underlying the nature and patterning of juvenile offending and the appropriate justice system responses to it" ([6], p. 579). Throughout these decisions, the justices cited the (at that time) emerging research on adolescent decision-making and recognized that juveniles differ significantly from adults with respect to their culpability and competence. The theme from that line of work summarized in several American Psychological Association briefs was to argue "against severe sentences for juvenile offenders primarily because juveniles' immaturity, vulnerability, and changeability make them less culpable than adults and accordingly that, as a result of their lower responsibility and ability to change, they should be deemed less responsible and thus less punishable. The APA reviewed evidence showing that adolescents are inherently more impulsive, short-sighted, and susceptible to peer influence" ([6], p. 599). Therefore, adolescents' decision-making ability is compromised by many more factors than is the decision-making ability of adults such that, as Brezina notes, helps us to understand "how and why individuals vary in their capacity to exercise agency".

I think one of the values of Brezina's middle-ground thesis is that it makes agency both an independent and dependent variable as shown in Fig. 1. This helps us to understand, both theoretical and ultimately empirically, that agency depends on certain
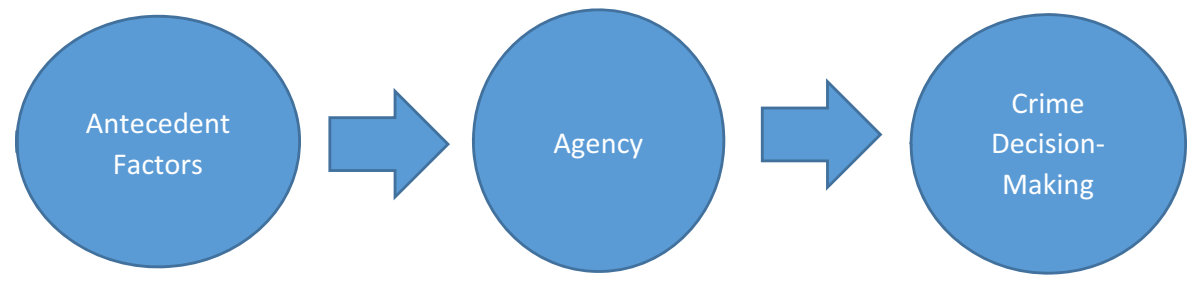

Fig. 1 Agency as an outcome and an influence 
capacities and resources and is influenced by several factors potentially differently at different periods of the life course and, in turn, may be related to offending in different ways and for different criminal decisions throughout the life course. And perhaps most relevant, Brezina's view is friendly to understanding decision-making in (a situational) context. Just because I go for seconds at the buffet table tonight does not mean I will make the same decision tomorrow. I may be more hungry today or my friend may be encouraging to have another piece of cake. The importance of situations is relevant here because "[h] umans develop capabilities and qualities that they bring to situations and even serve to help them select, within structurally available choices, life course trajectories, what Hitlin and Elder [3] refer to as life course agency" ([4], p.1465). As well, Fig. 1 could look quite different for people at age 6, 16, 26, and 46, for males and females, across race/ethnicity, cross-culturally, and so forth. Thus, agency fits nicely into developmental/life-course criminology and opens up many empirical questions. And it also helps us make better justice-oriented decisions by helping us to understand how decision-making may vary across and within persons over time and, therefore, offers the view that agency can change - and change for the better.

In closing, agency can and should be a measurable construct and by recognizing it in this manner, a great number of questions emerge: What does agency look like at different periods of the life course? What factors influence agency at different periods of the life course? How does agency predict antisocial and criminal behavior over the life course and how well does it do so? Is there a point where agency becomes routine, almost habit-like? How do we measure agency over the life course in developmentally appropriate ways? How do we measure agency in situational contexts, other than simulated laboratory experiments? Given the differences observed in offending patterns over the life course across both race and gender [9], is agency useful for illuminating those differences? Thinking of agency in a dynamic and situational manner over the life course opens up many research questions, the outcomes of which will undoubtedly spur additional theoretical work and show up in $J D L C C$ !

\section{References}

1. Brezina, T. (2019). Freedom of action, freedom of choice, and desistance from crime: pitfalls and opportunities in the study of human agency. Journal of Developmental and Life-Course Criminology, this issue.

2. Cullen, F. T. (2017). Choosing our criminological future: reservations about human agency as an organizing concept. Journal of Developmental and Life-Course Criminology, 3, 373-379.

3. Hitlin, S., \& Elder, Jr., G.H. (2007). Time, self, and the curiously abstract concept of agency. Sociological Theory, 25, 170-191.

4. Hitlin, S., \& Kirkpatrick Johnson, M. (2015). Reconceptualizing agency within the life course: the power of looking ahead. American Journal of Sociology, 120, 1429-1472.

5. Laub, J. H., \& Sampson, R. J. (2003). Shared beginnings, divergent lives: delinquent boys to age 70. Cambridge: Harvard University Press.

6. Monahan, K., Steinberg, L., \& Piquero, A. R. (2015). Juvenile justice policy and practice: a developmental perspective. In M. Tonry (Ed.), Crime and justice: A review of research (Vol. 44, pp. 577-619). Chicago: University of Chicago Press.

7. Paternoster, R. (2017). Happenings, acts, and actions: articulating the meaning and implications of human agency for criminology. Journal of Developmental and Life-Course Criminology, 3, 350-372.

8. Piquero, A. R. (2004). The intermittency of criminal careers. In S. Maruna \& R. Immarigeon (Eds.), Offender re-entry and desistance (pp. 102-129). Albany: SUNY Press. 
9. Piquero, A. R. (2015). Understanding race/ethnicity differences in offending across the life course: gaps and opportunities. Journal of Developmental and Life-Course Criminology, 1, 21-32.

10. Piquero, A. R., Farrington, D. P., \& Blumstein, A. (2003). The criminal career paradigm: background and recent developments. In M. Tonry (Ed.), Crime and justice: a review of research (Vol. 30, pp. 359-506). Chicago: University of Chicago Press.

11. Piquero, A. R., Paternoster, R., Pogarsky, G., \& Loughran, T. (2011). Elaborating the individual difference component in deterrence theory. Annual Review of Law and Social Science, 7, 335-360.

12. Wikström, P.-O., Oberwittler, D., Treiber, K., \& Hardie, B. (2012). Breaking rules: The social and situational dynamics of young People's urban crime. Oxford: Oxford University Press.

Publisher's Note Springer Nature remains neutral with regard to jurisdictional claims in published maps and institutional affiliations. 